\title{
Differential regulation of Igf1 and Igf 2 mRNA levels in tilapia hepatocytes: effects of insulin and cortisol on GH sensitivity
}

\author{
Andrew L Pierce, Jason P Breves, Shunsuke Moriyama ${ }^{1}$, Tetsuya Hirano and E Gordon Grau \\ Hawaii Institute of Marine Biology, University of Hawaii, Kaneohe, Hawaii 96744, USA \\ ${ }^{1}$ School of Marine Biosciences, Kitasato University, Sanriku, Iwate 022-0101, Japan \\ (Correspondence should be addressed to E G Grau; Email: grau@hawaii.edu)
}

\begin{abstract}
Igf1 and Igf2 stimulate growth and development of vertebrates. In mammals, liver-derived endocrine Igf1 mediates the growth promoting effects of $\mathrm{GH}$ during postnatal life, whereas Igf2 stimulates placental and fetal growth and is not regulated by GH. Insulin enhances Igf1 production by the mammalian liver directly, and by increasing hepatocyte sensitivity to $\mathrm{GH}$. We examined the regulation of igf1 and igf 2 mRNA levels by $\mathrm{GH}$, insulin, and cortisol, and the effects of insulin and cortisol on GH sensitivity in primary cultured hepatocytes of tilapia, a cichlid teleost. GH increased mRNA levels of both igf 1 and igf 2 in a concentration-related and biphasic manner over the physiological range, with a greater effect on igf $2 \mathrm{mRNA}$ level. Insulin increased basal igf 2
\end{abstract}

mRNA level, and strongly increased GH-stimulated igf2 mRNA level, but slightly reduced basal igf1 mRNA level and did not affect GH-stimulated igf1 mRNA level. Cortisol inhibited GH stimulation of igf1, but increased GH stimulation of igf $2 \mathrm{mRNA}$ level. The synergistic effect of insulin and GH on igf2 mRNA level was confirmed in vivo. These results indicate that insulin and cortisol differentially modulate the response of igf 1 and igf $2 \mathrm{mRNA}$ to GH in tilapia hepatocytes, and suggest that the regulation of liver Igf2 production differs between fish and mammals. Regulation of liver Igf2 production in fish appears to be similar to regulation of liver Igf1 production in mammals.

Journal of Endocrinology (2011) 211, 201-210

\section{Introduction}

The insulin-like growth factors (Igf1 and Igf2) are mitogenic peptides that regulate vertebrate growth (Humbel 1990, Jones \& Clemmons 1995, Reinecke \& Collet 1998). The Igfs are members of the evolutionarily ancient insulin-like family of peptides, found throughout the metazoans. Conserved features of the insulin-like peptides include regulation by nutritional status, and roles in nutrient metabolism, growth, development, reproduction, and aging (Tatar et al. 2003). Igf1 is thought to have arisen from insulin during the transition from chordates to primitive vertebrates, and Igf2 to have arisen from Igf1 in the common ancestor of the bony and cartilaginous fishes (Reinecke \& Collet 1998). Both Igfs act through the same membrane receptor, the type 1 Igf receptor, and the activity of both Igfs is modulated by multiple Igf-binding proteins. Both Igfs have a dual mode of action as local and as endocrine growth factors. Local Igfs are produced throughout the body; whereas endocrine Igfs are mainly produced by the liver.

Liver-derived circulating Igf1 plays an essential role in postembryonic mammals as the primary mediator of $\mathrm{GH}-$ dependent growth. As developed in the somatomedin hypothesis, pituitary GH stimulates liver production of Igf1, which feeds back to inhibit GH secretion in the GH/Igf endocrine axis (Humbel 1990, Jones \& Clemmons 1995, Phillips et al. 1998). In mice, both endocrine and local Igf1 play biologically significant roles in growth regulation (Stratikopoulos et al. 2008). Nutritional and metabolic status regulate the GH/Igf axis through direct effects on the liver, and by modulating liver sensitivity to GH. In catabolic states such as fasting and disease, liver production of Igf1 becomes resistant to stimulation by GH (Thissen et al. 1994, 1999). Metabolically responsive hormones link the anabolic/ catabolic state of the animal to liver $\mathrm{GH}$ sensitivity. Insulin directly increases hepatocyte Igf1 production, and strongly increases hepatocyte responsiveness to $\mathrm{GH}$ in vivo (Griffen et al. 1987, Butler et al. 2003), and in mammalian and avian primary hepatocyte culture (Tollet et al. 1990, Boni-Schnetzler et al. 1991, Houston \& O’Neill 1991, Phillips et al. 1998). Glucocorticoids induce liver GH resistance (Rodgers et al. 1994, Brameld et al. 1995, Beauloye et al. 1999).

In all vertebrate classes, igf 2 is highly expressed during embryogenesis, and stimulates growth in embryonic tissues (Jones \& Clemmons 1995, Reinecke \& Collet 1998, Wood et al. 2005, White et al. 2009). In contrast, igf1 expression is low during embryogenesis and increases with the onset of postnatal GH-dependent growth. It is thought that liver Igf2 
production is not strongly stimulated by $\mathrm{GH}$ or other hormones in postnatal mammals (Humbel 1990, Holly 1998). The lack of a clear picture of the regulation and function of endocrine Igf2 in postnatal mammals may be due to the central role of Igf 2 in the development of the placenta. Igf2 is a principal regulator of the size and exchange capacity of the placenta. The parent-offspring evolutionary conflict theory predicts that this role as a mediator of maternal-fetal resource partitioning has resulted in selection on igf 2 and divergence of Igf2 regulation and function (Haig 1993, O'Neill et al. 2007). A recent study in placental guppies supports this scenario (O'Neill et al. 2007). This suggests that Igf2 physiology may fundamentally differ between placental and non-placental vertebrates.

Recent studies show that teleost fishes including salmonids, sea bream, carp, catfish, eels, rabbitfish, sea bass, and hybrid striped bass, as well as the dogfish, an elasmobranch, differ from mammals in that liver igf 2 gene expression and plasma Igf2 levels are stimulated by $\mathrm{GH}$ and respond to metabolic status (Shamblott et al. 1995, Tse et al. 2002, Vong et al. 2003a, Peterson et al. 2004, 2005, Carnevali et al. 2005, Gabillard et al. 2006, Wilkinson et al. 2006, Ayson et al. 2007, Terova et al. 2007, Gahr et al. 2008, Moriyama et al. 2008a, b, Picha et al. 2008b, Ponce et al. 2008, Devlin et al. 2009, Peterson \& Waldbieser 2009, Eppler et al. 2010, Pierce et al. 2010). In primary cultured coho salmon hepatocytes, insulin directly increased iff 2 mRNA, and strongly increased the response of igf2 mRNA to $\mathrm{GH}$, but suppressed the response of igf1 mRNA to GH (Pierce et al. 2005, 2010). Thus, the regulation of liver igf 2 gene expression in coho salmon is similar to the regulation of liver igf 1 gene expression in mammals. We hypothesized that this may be the case in teleost fishes in general. To test this hypothesis, we examined the regulation of igf1 and igf 2 gene expression by $\mathrm{GH}$, insulin, and cortisol, and the effects of insulin and cortisol on GH sensitivity in primary cultured hepatocytes of a cichlid teleost, the Mozambique tilapia (Oreochromis mossambicus).

\section{Materials and Methods}

\section{Animals}

Mozambique tilapia were maintained in 7001 outdoor freshwater flow-through tanks at the Hawaii Institute of Marine Biology. Fish were fed $\sim 2 \%$ body weight per day in two daily feedings (Silver Cup Trout Chow, Portco Corporation, Vancouver, BC, Canada). Water temperature was maintained at $25-28{ }^{\circ} \mathrm{C}$. Fish used in hepatocyte culture studies were 2- to 3-year-old males weighing 300-600 g, whereas fish used in the in vivo injection experiment were 1-year-old males weighing 60-80 g. All experiments were conducted under approved protocols in accordance with the principles and procedures of the Institutional Animal Care and Use Committee, University of Hawaii.
Hepatocyte isolation and culture

Fish were fasted for 1 day before hepatocyte isolation. Fish were first anesthetized by immersion in a nonlethal concentration of buffered tricaine methanesulfonate (MS-222, Argent Chemical Laboratories, Redmond, WA, USA, $0.5 \mathrm{~g} / \mathrm{l}$ ), and i.p. injected with lithium heparin (Sigma, $10000 \mathrm{U} / \mathrm{kg}$ ). After $5 \mathrm{~min}$, fish were killed by immersion in a lethal concentration of MS-222 $(2 \cdot 0 \mathrm{~g} / \mathrm{l})$. Immediately after opercular movements stopped, fish were placed left side down on a sterile elevated screen. The right side of the peritoneal cavity was cut away. The gall bladder was punctured and drained, and the empty gall bladder and fat and connective tissue were dissected away, exposing the hepatic portal vein. The vessel was cut partway through and a polyethylene cannula was inserted and pushed toward the liver, until the tip was near where the vessel begins to ramify into the liver, and tied in place. The heart was removed to allow drainage. The liver was perfused with $\mathrm{Ca}^{++}$-free Hanks' buffered saline solution (HBSS) for 20-30 min at a flow rate of $1.5 \mathrm{ml} / \mathrm{min}$. Perfusion then continued with $6 \cdot 5-7 \cdot 5 \mathrm{mg} / 100 \mathrm{ml}$ collagenase (type IV, Sigma C5138, lot \#085K8618), made fresh in $\mathrm{Ca}^{++}$-free HBSS and sterile filtered immediately before use. Collagenase perfusion continued until cracks appeared on the surface of the liver, typically 8-12 min. During $\mathrm{Ca}^{++}$-free HBSS and collagenase perfusion, the liver was massaged gently every $5 \mathrm{~min}$. When digestion was complete, the liver was removed from the fish and placed in a sterile Petri dish in ice cold $\mathrm{Ca}^{++}$-free HBSS. Undigested sections of liver tissue, fat, connective tissue, and blood clots were dissected away, digested tissue was chopped fine with a razor blade, and cells were mashed through a $70 \mu \mathrm{m}$ filter. Cells were collected in $50 \mu \mathrm{l}$ of ice cold $\mathrm{Ca}^{+}{ }^{+}$-free HBSS and pelleted (60 g, $\left.5 \mathrm{~min}\right)$. Cells were resuspended in recovery medium $\left(\mathrm{Ca}^{++}\right.$-free HBSS supplemented with $1.5 \mathrm{mM} \mathrm{CaCl}_{2}, 2 \%$ cell culture grade BSA, $3 \mathrm{mM}$ glucose, and $1 \times$ Gibco MEM essential and non-essential amino acid solutions). Cells were washed three times in recovery medium, and then settled on ice for 1-2 h. After settling, cells were resuspended in culture medium (modified RPMI 1640 medium, Gibco BRL; $20 \mathrm{mM}$ HEPES, $5 \mathrm{mM} \mathrm{NaHCO}$, and $0 \cdot 2 \% \mathrm{BSA}$ ) and washed twice. Cells were counted and examined for viability by trypan blue exclusion, and then plated at a density of $1-2 \times 10^{6}$ cells $/ \mathrm{ml}, 0.5 \mathrm{ml} /$ well on Falcon Primaria 24-well plates and incubated at $25{ }^{\circ} \mathrm{C}$ under plain air. Cells were isolated from individual fish and pooled if necessary. Cells were allowed to adhere to culture plates for an initial period as described in the Results section, and then medium was changed to test medium containing hormones. Native tilapia GH was purified by HPLC (Specker et al. 1985). Native bovine insulin and cortisol were purchased from Sigma (insulin Sigma I6634, lot 096K16911, activity 28 USP units/mg by HPLC). Ethanol $(0 \cdot 1 \%)$ was added to medium for all treatments in experiments testing the effects of cortisol. Cultures were stopped by adding Tri-Reagent (MRC, Cincinnati, OH, USA) to wells and freezing culture plates at $-80^{\circ} \mathrm{C}$. 
In vivo injection experiment

Freshwater-acclimated fish were fasted for $24 \mathrm{~h}$ and injected with hormones. Fish were not fed post-injection. During injection, fish were anesthetized (MS-222, $0.5 \mathrm{~g} / \mathrm{l}$ ) and injected with saline vehicle $(0.9 \% \mathrm{NaCl}, 1 \mu \mathrm{l} / \mathrm{g}$ body weight), native ovine $\mathrm{GH}(5 \mu \mathrm{g} / \mathrm{g}$ body weight, NIDDK oGH-15, lot AFP 9220A, activity $1.52 \mathrm{IU} / \mathrm{mg}$ in terms of Bovine $\mathrm{GH}$ International Standard 55/1), native bovine insulin $(5 \mu \mathrm{g} / \mathrm{g}$ body weight, Sigma), or insulin and GH. Fish were fatally anesthetized $6 \mathrm{~h}$ later, and liver tissue was collected. Liver was homogenized immediately in Tri-Reagent and stored at $-80{ }^{\circ} \mathrm{C}$ until RNA isolation.

$R N A$ isolation, real-time quantitative RT-PCR, and plasma glucose assays

RNA was isolated following the MRC protocol, with bromochloropropane as the phase separation reagent and two $70 \%$ ethanol washes. RNA was quantified and purity assessed by spectrophotometry (Nanodrop ND-1000, Wilmington, DE, USA: RNA yield 286-906 ng/well, A260/280 1.90$2 \cdot 18)$, RNA was diluted to $10-50 \mathrm{ng} / \mu \mathrm{l}$, and first strand cDNA was synthesized with a kit (qScript cDNA Supermix, Quanta BioSciences, Gaithersburg, MD, USA). Hepatocyte and liver igf1 and reference gene (acidic ribosomal phosphoprotein P0 (arp) and elongation factor $1 \alpha(e f 1 \alpha))$ mRNA expression levels were quantified as described previously (Pierce et al. 2007, Breves et al. 2010). Hepatocyte and liver igf2 mRNA levels were quantified with a quantitative RT-PCR (qPCR) assay across the predicted exons $3 / 4$ boundary (F primer: AGCCACCTCTCTACAGGTCATACC and R primer: ACTTCACGGTCACATGTTGCTT, hydrolysis probe: FAM-TGCCCGCACTAAAACAGGAAGTTCAGA-BHQ, amplicon size: $80 \mathrm{bp}$ ), which was validated (PCR efficiency 91-95\%, biological template serial dilutions parallel to PCR product standard curve, no bias across PCR plate, no signal from genomic DNA or RT reactions with the reverse transcriptase omitted, single peak in melting curve analysis in assay run with SYBER green and probe omitted). All qPCR assays were run in 96-well format on an Applied BioSystems (ABI, Foster City, CA, USA) StepOne Plus qPCR machine, using standard cycling conditions. Assays were run using ABI Gene Expression Master Mix in a reaction volume of $15 \mu \mathrm{l}$, with primers and probe at a concentration of $200 \mathrm{nM}$. Gene expression levels for individual targets were quantified using PCR product standard curves and then normalized by dividing the expression level of a gene of interest in a given sample by the expression level of an appropriate reference gene in that sample as described previously (Pierce et al. 2007). Gene expression data for hepatocyte culture experiments were normalized to the expression level of arp, whereas gene expression data for the in vivo injection experiment were normalized to the expression level of ef $1 \alpha$. Statistically detectable differences in the $C_{\mathrm{T}}$ for arp were not found between treatments in any hepatocyte culture experiment, and statistically detectable differences in the $C_{\mathrm{T}}$ for ef $1 \alpha$ were not found between treatments in the injection experiment, providing evidence that treatments did not affect our reference genes (ANOVA on replicate culture plate wells or fish). Plasma glucose was measured by the hexokinase method by a kit (GAHK-20, Sigma).

\section{Data analysis}

Gene expression data were $\log 2$ transformed before analysis. Treatment effects were examined by one- or two-way ANOVA, followed by the Student-Newman-Keuls test. Results were considered statistically detectable at $P<0 \cdot 05$. Data analysis was conducted with Prism (GraphPad Software, San Diego, CA, USA). Data are given as mean \pm s.D. To establish tilapia hepatocyte culture, we used pooled cells (time course experiment: pooled cells from two fish and $\mathrm{GH}$ concentration-response experiment: pooled cells from two fish). In these experiments, our experimental unit is the well, and our statistical inferences are restricted to the pool of cells used. To show that effects were repeatable, we used independent cultures (insulin GH and factorial experiment: separately cultured cells from four fish and cortisol and $\mathrm{GH}$ factorial experiment: separately cultured cells from three fish). In these experiments, our experimental unit is the cell preparation, and our statistical inferences are to tilapia hepatocytes cultured using our methods. Owing to differences in the magnitude of response of different cultures, $\log 2$

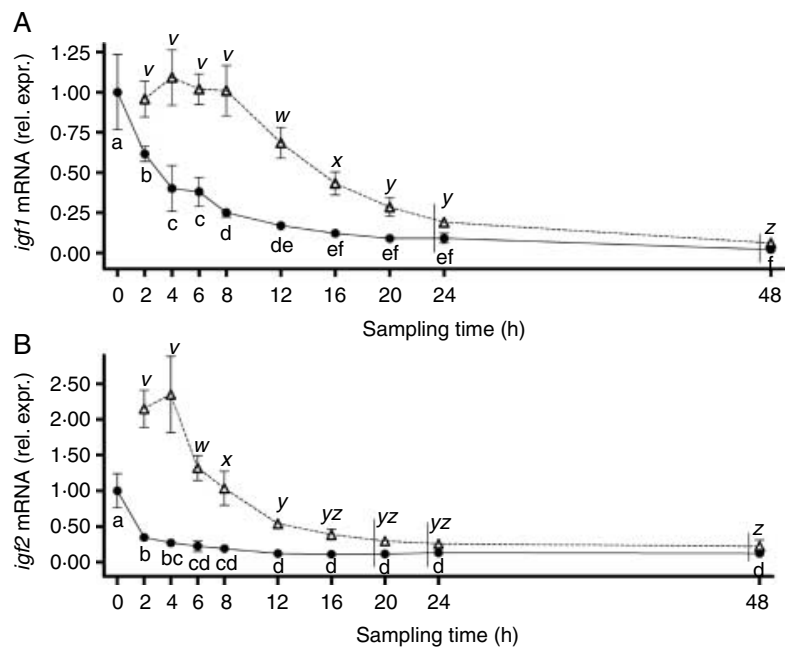

Figure 1 Effects of incubation time and $\mathrm{GH}$ treatment on (A) igf1 and (B) igf2 mRNA level in primary cultured tilapia hepatocytes and expressed relative to the time 0 control treatment (rel. expr.). Filled circles, control; open triangles, native tilapia $\mathrm{GH}, 100 \mathrm{ng} / \mathrm{ml}$ $\left(4.5 \times 10^{-9} \mathrm{M}\right)$. Hepatocytes were plated and preincubated in hormone-free medium for $4 \mathrm{~h}$ before addition of test medium. Letters indicate statistically detectable differences over time within each treatment (Student-Newman-Keuls test, $P<0 \cdot 05, n=6-8$ wells per point). Points connected by a vertical line to the left are not statistically detectably different between treatments. Symbols show the mean value for each treatment at each time point; error bars show S.D., and are shown only when larger than symbols. 

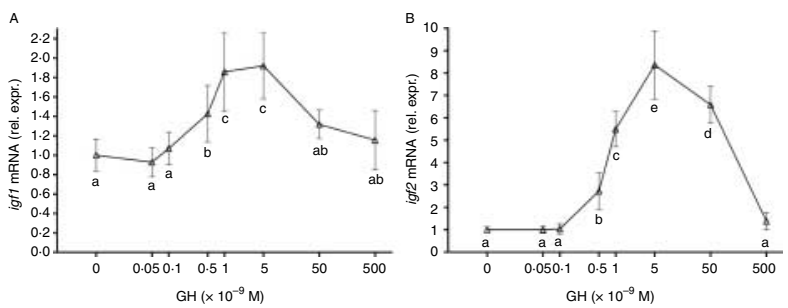

Figure 2 Effect of native tilapia GH concentration on (A) igf1 and (B) igf2 mRNA level in primary cultured tilapia hepatocytes and expressed relative to the $0 \mathrm{GH}$ control treatment (rel. expr.). Hepatocytes were preincubated for $4 \mathrm{~h}$, and incubated with $\mathrm{GH}$-containing medium for $6 \mathrm{~h}$. Letters indicate statistically detectable differences among $\mathrm{GH}$ concentrations (StudentNewman-Keuls test, $P<0 \cdot 05, n=7-12$ wells per point). Symbols show the mean value at each $\mathrm{GH}$ concentration; error bars show S.D.

transformed data from these experiments were normalized by multiplying by the average response to $\mathrm{GH}$ in all cultures divided by the response to $\mathrm{GH}$ in a given culture. To characterize concentration-response relationships, we used pooled cells (insulin concentration-response experiment: pooled cells from two fish and cortisol concentration-response experiment: pooled cells from two fish). In these experiments, our experimental unit is the well, and our statistical inferences are restricted to the pool of cells used.

\section{Results}

Under our experimental conditions, freshly isolated tilapia hepatocytes adhered to culture plates after $4 \mathrm{~h}$. Shorter adherence times resulted in substantial loss of cells when changing medium. Consequently, initial $4 \mathrm{~h}$ incubation in plain medium without hormones or serum was employed in all experiments. Gene expression levels of both igf1 and igf2 decreased rapidly during primary culture (Fig. 1, $n=6-8$ wells per point, two-way ANOVA igf1: time $55 \%$ of variation, $P<0 \cdot 0001 ; \mathrm{GH} 30 \%, P<0 \cdot 0001$; interaction $12 \%, P<0.0001$ and igf2: time $38 \%, P<0 \cdot 0001 ; \mathrm{GH} 30 \%$, $P<0 \cdot 0001$; interaction 26\%, $P<0 \cdot 0001$ ). After $24 \mathrm{~h}$, control igf1 mRNA levels had decreased to $0 \cdot 091 \pm 0 \cdot 011$ and igf 2 mRNA levels to $0 \cdot 128 \pm 0 \cdot 009$-fold time 0 levels. The addition of $\mathrm{GH}\left(100 \mathrm{ng} / \mathrm{ml}=4.5 \times 10^{-9} \mathrm{M}\right)$ to the medium increased mRNA levels of both igfs versus time-matched controls. Basal and GH-stimulated igf1 decreased with time in previous studies with primary tilapia and salmon hepatocytes (Schmid et al. 2000, Pierce et al. 2004). Based on the results for these and other transcripts, an incubation time of $6 \mathrm{~h}$ was selected, giving a total culture age of $10 \mathrm{~h}$.

The response of both igfs-GH was concentrationdependent and biphasic (Fig. 2, $n=7-12$ wells per point, one-way ANOVA igf1: $P<0 \cdot 0001$ and igf2: $P<0 \cdot 0001)$. For both igfs, mRNA levels were statistically detectably increased at $0.5 \times 10^{-9} \mathrm{M} \mathrm{GH}$, maximal response occurred at $5 \times 10^{-9} \mathrm{M} \mathrm{GH}$ (igf1 $1.92 \pm 0 \cdot 12$-fold $0 \mathrm{GH}$ controls and igf $28 \cdot 36 \pm 0 \cdot 54$-fold $0 \mathrm{GH}$ control), and the response was reduced to control levels at $500 \times 10^{-9} \mathrm{M}$ GH. Based on these results, co-incubation with $5 \times 10^{-9} \mathrm{M} \mathrm{GH}$ was used to assess the effects of insulin and cortisol on GH sensitivity.

The effects of insulin $\left(10^{-6} \mathrm{M}\right)$ alone and in combination with $\mathrm{GH}\left(5 \times 10^{-9} \mathrm{M}\right)$ were tested in four primary hepatocyte cultures. Although the magnitude of effect varied, insulin, GH, and GH plus insulin treatment affected igf1 and igf 2 mRNA levels similarly in all cultures (igf1: insulin: $0 \cdot 89,0 \cdot 75,0 \cdot 80$, 0.76; GH: 2·48, 1·94, 1·48, 1·48; GH plus insulin: 1·86, 1·68, $1 \cdot 45,1 \cdot 63$-fold controls respectively and igf2: insulin: $1 \cdot 34$, 3·27, 1·98, 4·03; GH: 1·82, 6.97, 3·16, 3·93; GH plus insulin: $2 \cdot 79,16 \cdot 87,7 \cdot 63,17 \cdot 23$-fold controls respectively). The effect of GH on igf 1 and igf $2 \mathrm{mRNA}$ levels was statistically detectable in all cultures (one-way ANOVA on replicate culture wells). To present data from all cultures, $\log 2$ transformed data were normalized to the average level of stimulation of each igf by GH (Fig. $3, n=4$ fish, one-way ANOVA igf1: $P<0 \cdot 0001$ and igf 2: $P<0 \cdot 0001)$. Insulin slightly suppressed basal igf1 mRNA levels $(0 \cdot 77 \pm 0 \cdot 06$-fold controls) but did not affect $\mathrm{GH}$-stimulated igf1 mRNA levels. Insulin increased basal igf 2 mRNA levels $(2 \cdot 44 \pm 0 \cdot 42$-fold controls), but to a lesser degree than GH (3.59-fold controls, calculation of S.D. precluded by normalization), and insulin plus GH strongly increased igf $2 \mathrm{mRNA}$ levels $(2 \cdot 71 \pm 0 \cdot 46$-fold GH alone).

The effect of insulin alone and in combination with $\mathrm{GH}\left(5 \times 10^{-9} \mathrm{M}\right)$ was further examined in a concentrationresponse study (Fig. 4, $n=8$ wells per point, two-way ANOVA igf1: insulin $1 \cdot 8 \%$ of variation, $P=0 \cdot 0661$; GH $73 \%$, $P<0.0001$; interaction $2.9 \%, P=0.0043$ and igf 2 : insulin $30 \%$ of variation, $P<0.0001 ; \mathrm{GH} 57 \%, P<0 \cdot 0001$; interaction $12 \%, P<0 \cdot 0001)$. GH increased igf1 and igf2 mRNA levels at all insulin concentrations, including 0 insulin (igf1 $1 \cdot 73 \pm 1 \cdot 6$-fold controls and igf2 $4 \cdot 40 \pm 0 \cdot 10$-fold controls). Insulin did not affect the response of igf1 mRNA levels to GH, and did not decrease basal igf1 mRNA levels. An apparent slight increase in GH-stimulated igf1 mRNA level with increasing insulin was not statistically detectable. Insulin increased basal igf2 levels, and strongly increased the response
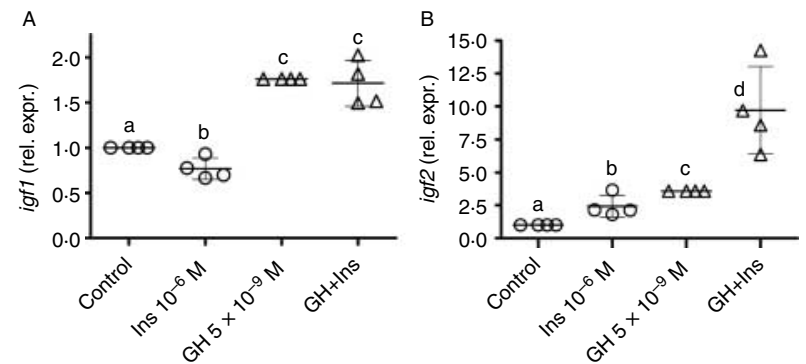

Figure 3 Effects of insulin (Ins, bovine, $10^{-6} \mathrm{M}$ ) treatment on basal and $\mathrm{GH}$-stimulated (A) igf1 and (B) igf2 mRNA level in primary cultured tilapia hepatocytes, expressed relative to the control treatment (rel. expr.). Symbols show replicate cultures from individual fish. Cultures from individual fish were normalized to the average response to $\mathrm{GH}$ of all cultures. Letters indicate statistically detectable differences among treatments (Student-Newman-Keuls test, $P<0 \cdot 05, n=4$ fish); error bars show S.D. 

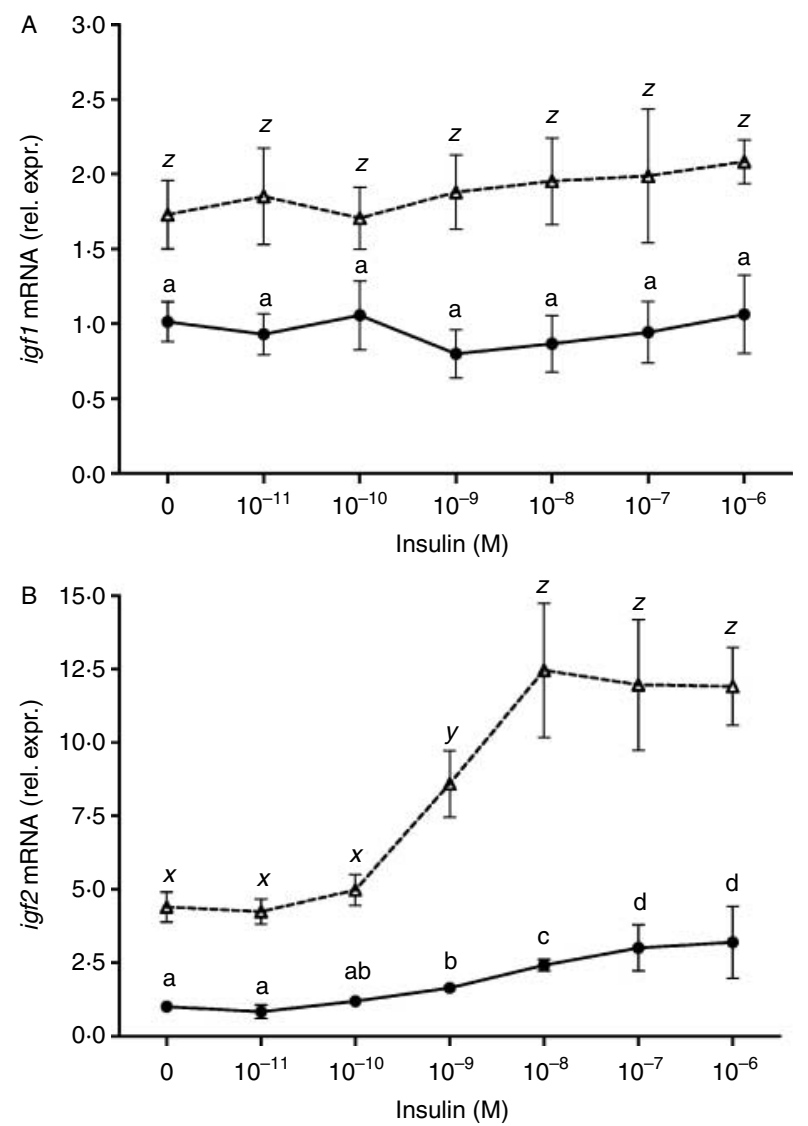

Figure 4 Effects of insulin concentration on basal and GH-stimulated (A) igf1 and (B) igf2 mRNA level in primary cultured tilapia hepatocytes and expressed relative to the 0 insulin $0 \mathrm{GH}$ control treatment (rel. expr.). Filled circles, control; open triangles, native tilapia $\mathrm{GH}, 5 \times 10^{-9} \mathrm{M}$. Letters indicate statistically detectable differences among insulin concentrations within each $\mathrm{GH}$ treatment (Student-Newman-Keuls test, $P<0 \cdot 05, n=8$ wells per point). The effect of $\mathrm{GH}$ treatment was statistically detectable at all insulin levels for both igf transcripts. Error bars show S.D.

of igf 2 to $\mathrm{GH}$. The increase in basal igf $2 \mathrm{mRNA}$ level became statistically detectable at $10^{-9} \mathrm{M}$ insulin, and was maximal at $10^{-6} \mathrm{M}$ insulin $(3 \cdot 20 \pm 0 \cdot 43$-fold 0 insulin controls). The increase in GH-stimulated igf 2 mRNA level also became statistically detectable at $10^{-9} \mathrm{M}$ insulin, and was maximal at $10^{-8} \mathrm{M}$ insulin $(2 \cdot 83 \pm 0 \cdot 18$-fold $\mathrm{GH}$ alone).

The effects of cortisol $\left(10^{-6} \mathrm{M}\right)$ alone and in combination with $\mathrm{GH}\left(5 \times 10^{-9} \mathrm{M}\right)$ were tested in three primary hepatocyte cultures. Although the magnitude of effect varied, cortisol, GH, and GH plus cortisol treatment affected igf1 and igf2 mRNA levels similarly in all cultures (igf1: cortisol: 0.93 , 1.11, 0.88; GH: 1.58, 1.52, 1.52; GH plus cortisol: 1.19, 1.31, 1.10-fold controls respectively and igf 2: cortisol: $0 \cdot 73$, $0 \cdot 77,0.59 ; \mathrm{GH}: 3 \cdot 43,4 \cdot 35,1 \cdot 77$; GH plus cortisol: $7 \cdot 59,8 \cdot 85,3 \cdot 82$-fold controls respectively). The effect of $\mathrm{GH}$ on igf1 and igf 2 mRNA levels was statistically detectable in all cultures (one-way ANOVA on replicate culture wells).
To present data from all cultures, $\log 2$ transformed data were normalized to the average level of stimulation of each igf by GH (Fig. $5, n=3$ fish, one-way ANOVA igf1: $P<0 \cdot 0001$ and igf: $P=0 \cdot 0001)$. Cortisol did not statistically detectably affect basal igf1 mRNA levels, but suppressed GH-stimulated igf1 mRNA levels $(0 \cdot 78 \pm 0 \cdot 038$-fold GH alone). There was a consistent but not statistically detectable trend toward suppression of basal igf 2 by cortisol $(P=0.1312 ; 0.65$ $\pm 0 \cdot 15$-fold controls). Cortisol strongly increased GHstimulated igf $2 \mathrm{mRNA}$ levels $(2 \cdot 65 \pm 0 \cdot 81$-fold GH alone).

The effect of cortisol alone and in combination with GH $\left(5 \times 10^{-9} \mathrm{M}\right)$ was further examined in a concentrationresponse study (Fig. 6, $n=7-8$ wells per point, two-way ANOVA iff1: cortisol $13 \%$ of variation, $P<0 \cdot 0001$; GH $48 \%$, $P<0 \cdot 0001$; interaction 4.5\%, $P<0.0001$ and igf2: cortisol $2 \cdot 2 \%$ of variation, $P<0 \cdot 0001 ;$ GH $84 \%, P<0 \cdot 0001$; interaction $5 \cdot 8 \%, P<0 \cdot 0001)$. GH increased igf1 and igf 2 mRNA levels at all cortisol concentrations, including 0 cortisol (igf1 1.86 $\pm 0 \cdot 045$-fold controls and igf $3 \cdot 74 \pm 0 \cdot 089$-fold controls). Cortisol did not affect basal igf $1 \mathrm{mRNA}$ levels, but reduced GH-stimulated if $1 \mathrm{mRNA}$ levels. The decrease in igf 1 mRNA level in cells co-incubated with GH became statistically detectable at $10^{-8} \mathrm{M}$ cortisol and was maximal at $10^{-6} \mathrm{M}$ cortisol $(0 \cdot 67 \pm 0 \cdot 028$-fold $\mathrm{GH}$ alone). Cortisol reduced basal igf 2 mRNA levels at levels of $10^{-8} \mathrm{M}$ and above $\left(0 \cdot 54 \pm 0 \cdot 037\right.$-fold control levels at $\left.10^{-6} \mathrm{M}\right)$. In contrast, cortisol increased GH-stimulated igf 2 mRNA levels. The increase became statistically detectable at $10^{-8} \mathrm{M}$ cortisol, was maximal at $10^{-7} \mathrm{M}(1 \cdot 50 \pm 0 \cdot 065$-fold $\mathrm{GH}$ alone $)$, and was statistically detectably reduced from maximal levels at $10^{-6} \mathrm{M}$.

In an analysis of all hepatocyte culture experiments employing $5 \times 10^{-9} \mathrm{M} \mathrm{GH}$, GH stimulation of igf $2 \mathrm{mRNA}$ levels was statistically detectably greater than $\mathrm{GH}$ stimulation of igf $1 \mathrm{mRNA}$ levels (igf $11 \cdot 7 \pm 0 \cdot 10$-fold control; igf2 $4 \cdot 2$ $\pm 0 \cdot 65$-fold control; $P=0 \cdot 0017$, $t$-test, $n=10$ ).

Fish were injected with insulin and $\mathrm{GH}$ to confirm the results of our in vitro experiments (Fig. 7, $n=7-8$ fish
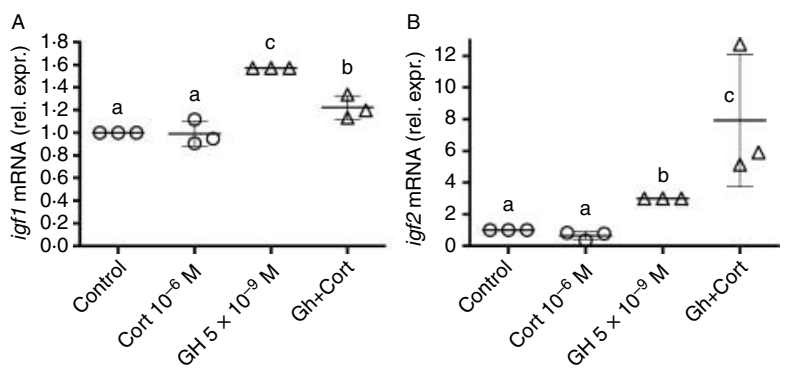

Figure 5 Effects of cortisol (Cort, $10^{-6} \mathrm{M}$ ) treatment on basal and $\mathrm{GH}$-stimulated (A) igf1 and (B) igf2 mRNA level in primary cultured tilapia hepatocytes, expressed relative to the control treatment (rel. expr.). Symbols show replicate cultures from individual fish. Cultures from individual fish were normalized to the average response to $\mathrm{GH}$ of all cultures. Letters indicate statistically detectable differences among treatments (Student-Newman-Keuls test, $P<0 \cdot 05, n=3$ fish per point); error bars show S.D. 

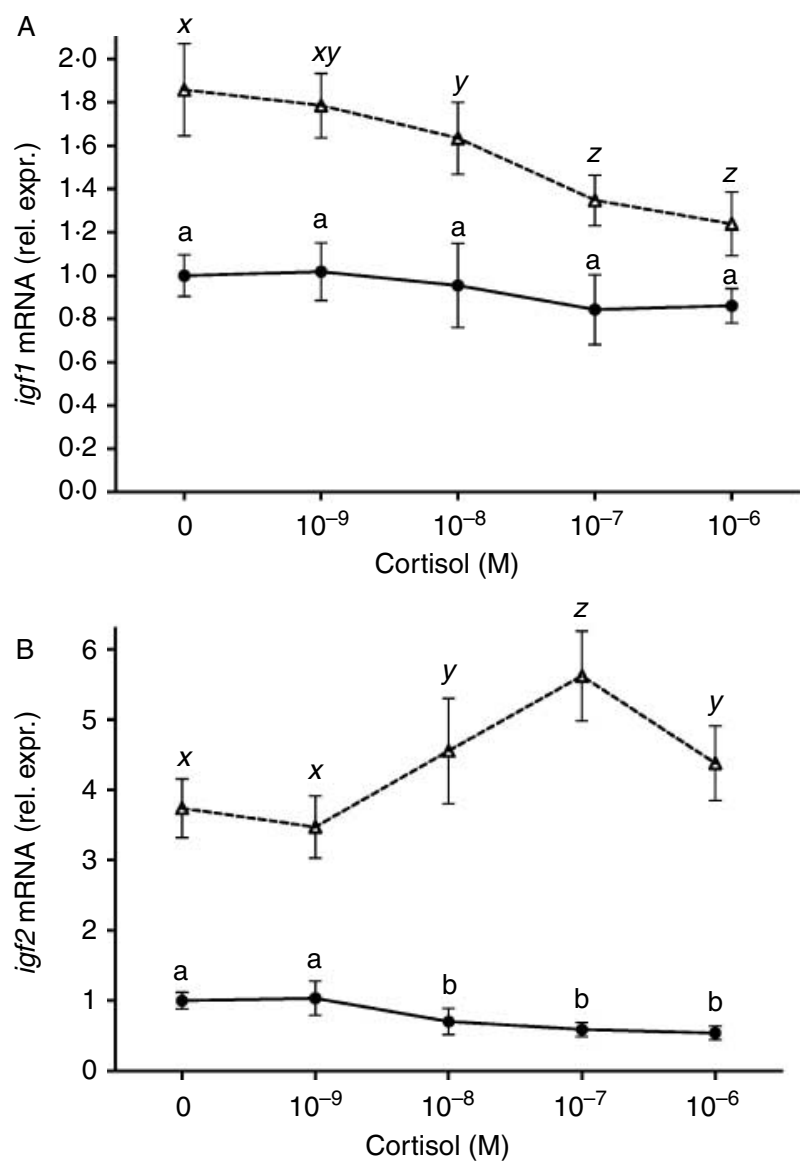

Figure 6 Effect of cortisol concentration on basal and GH-stimulated (A) igf1 and (B) igf2 mRNA level in primary cultured tilapia hepatocytes and expressed relative to the 0 cortisol $0 \mathrm{GH}$ control treatment (rel. expr.). Filled circles, control; open triangles, native tilapia $\mathrm{GH}, 5 \times 10^{-9} \mathrm{M}$. Letters indicate statistically detectable differences among cortisol concentrations within each $\mathrm{GH}$ treatment (Student-Newman-Keuls test, $P<0 \cdot 05, n=7-8$ wells per point). The effect of $\mathrm{GH}$ treatment was statistically detectable at all cortisol levels for both igf transcripts. Error bars show S.D.

per point, one-way ANOVA glucose: $P=0 \cdot 0010$; igf 1 : $P<0 \cdot 0001$; and igf $2: P=0 \cdot 0002)$. Insulin and $\mathrm{GH}$ doses similar to those used in previous studies in fish were used, and plasma glucose was measured to confirm the expected hypoand hyperglycemic effects of insulin and GH respectively (Mommsen \& Plisetskaya 1991, Wood et al. 2005). Insulin injection (bovine, $5 \mu \mathrm{g} / \mathrm{g}$ body weight) reduced plasma glucose levels at $6 \mathrm{~h}$. GH injection (ovine, $5 \mu \mathrm{g} / \mathrm{g}$ body weight) caused apparent increase in plasma glucose. However, this increase was not statistically detectable under our experimental conditions $(\alpha=0 \cdot 05$; probability of type 1 error $=0.156$ and probability of type 2 error $=0 \cdot 220$ ) . Nevertheless, co-injection of GH with insulin prevented the insulin-induced decrease in plasma glucose. GH injection increased liver mRNA levels of both igfs (igf1: $1 \cdot 94 \pm 0 \cdot 17$ and igf2: $7 \cdot 08 \pm 0 \cdot 75$-fold controls). An apparent decrease in igf1
mRNA level with insulin injection was not statistically detectable, and insulin injection did not change igf 2 mRNA level; however, co-injection with GH and insulin increased mRNA levels of both igf1 and igf2 compared with levels produced by injection with GH alone (igf1: 1.43 $\pm 0 \cdot 12$ and igf2: 1.52 $\pm 0 \cdot 13$-fold GH alone). The effects of GH and GH plus insulin on igf 2 mRNA levels were statistically detectably greater than effects on igf1 mRNA levels.

\section{Discussion}

This study shows that igf1 and igf 2 mRNA levels are differentially regulated by insulin and cortisol in tilapia hepatocytes through direct effects and differential modulation of GH sensitivity. Insulin increased basal igf $2 \mathrm{mRNA}$ levels and strongly increased the response of igf $2 \mathrm{mRNA}$ levels to $\mathrm{GH}$, but did not increase basal igf1 mRNA levels or the response of igf $1 \mathrm{mRNA}$ levels to GH. Similar results were found in salmon hepatocytes (Pierce et al. 2005, 2010), suggesting that insulin and GH synergistically stimulate liver Igf2 but not Igf1 production in teleost fishes.

Both igf1 and igf2 mRNA levels were stimulated by GH in tilapia primary hepatocytes, as has been found in previous in vitro studies in teleost fishes and elasmobranches (Shamblott et al. 1995, Schmid et al. 2000, Pierce et al. 2004, 2010, Leung et al. 2008, Moriyama et al. 2008a, b). Recent in vivo studies have shown that GH treatment increases liver igf 2 mRNA levels in a wide variety of fish species (see Introduction for citations), which is consistent with our results. Circulating GH levels in tilapia range from $\sim 0.05$ to $1 \times 10^{-9} \mathrm{M}$ (Weber \& Grau 1999, Uchida et al. 2003, Fox et al. 2009), suggesting that physiological regulation of liver igf1 and igf 2 by GH occurs on the left side of the concentration-response curve. In humans, $\mathrm{GH}$ injection increased liver Igf2 transcripts from promoters $\mathrm{P} 2$ and $\mathrm{P} 4$, but did not change overall Igf 2 transcript levels, and GH treatment increased P2 transcripts in primary human hepatocytes (Olivecrona et al. 1999, von Horn et al. 2002). As far as we are aware, this is the only recent report of $\mathrm{GH}-$ dependent liver Igf2 gene expression in mammals. This suggests that teleost fishes differ from mammals in that fish liver igf2 gene expression is $\mathrm{GH}$-dependent.

Incubation with insulin stimulated igf 2 mRNA level in tilapia primary hepatocytes, and co-incubation with insulin and GH strongly increased igf $2 \mathrm{mRNA}$ levels over levels with insulin or GH alone. In contrast, basal igf1 mRNA level was slightly suppressed by insulin, and GH-stimulated igf1 mRNA level did not respond to insulin. A concentration-response study showed strong enhancement of the stimulation of igf 2 from $10^{-10}$ to $10^{-8} \mathrm{M}$ insulin in the presence of GH. In the same cells, igf 1 responded reliably to $\mathrm{GH}$, but the response was not modulated by insulin, suggesting that the synergistic interaction between insulin and $\mathrm{GH}$ in the regulation of igf 2 mRNA level is specific to this transcript. Although circulating insulin levels in tilapia have not been measured, fish plasma insulin ranges from 0.2 to $5 \times 10^{-9} \mathrm{M}$ 


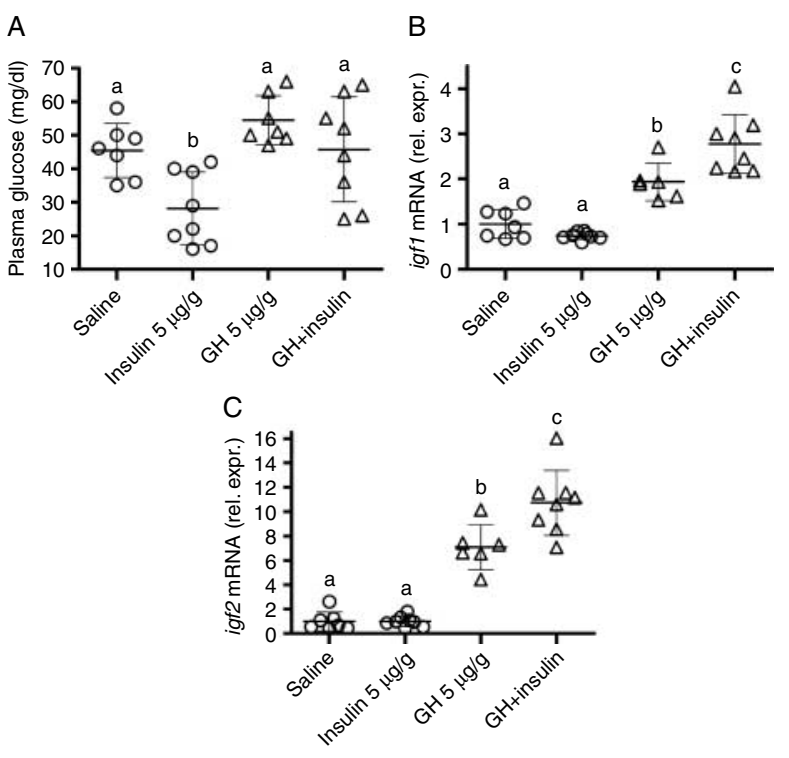

Figure 7 Effects of insulin (bovine, $5 \mu \mathrm{g} / \mathrm{g}$ body weight) and $\mathrm{GH}$ (ovine, $5 \mu \mathrm{g} / \mathrm{g}$ body weight) injection and co-injection on (A) plasma glucose concentration, (B) liver igf1 mRNA level, and (C) liver igf2 mRNA level in male tilapia. Plasma and liver samples were taken $6 \mathrm{~h}$ after injection. mRNA levels are expressed relative to the saline injected control treatment (rel. expr.). Symbols show individual fish. Letters indicate statistically detectable differences among treatments (Student-Newman-Keuls test, $P<0 \cdot 05, n=6-8$ fish per point). Error bars show S.D.

(Mommsen \& Plisetskaya 1991), suggesting that regulation of igf2 occurs over the physiological range. In salmon hepatocytes, basal and GH-stimulated igf2 responded similarly to insulin, whereas GH-stimulated igf1 was suppressed by insulin (Pierce et al. 2005, 2010). Thus, insulin stimulation of basal liver igf2 but not igf1 gene expression, and enhancement of the response of liver igf2 but not igf1 to $\mathrm{GH}$, appear to be conserved in teleost fishes.

Injection of hormones confirmed in vivo $\mathrm{GH}$ stimulation of liver igf 2 gene expression, and a positive interaction between insulin and $\mathrm{GH}$ in stimulation of liver igf2 gene expression. However, insulin injection alone did not result in a statistically detectable increase in liver igf2 gene expression, which differs from our in vitro results. This may have been caused by the decrease in blood glucose seen after insulin injection, or a cortisol response to the injection. Glucose positively regulates igf2 gene expression in fetal rat hepatocytes (Goya et al. 1999), and in this study, cortisol tended to suppress basal igf 2 in vitro. Injection of GH-stimulated igf1 gene expression, consistent with our in vitro results and previous studies (Kajimura et al. 2001, Eppler et al. 2010). Injection of insulin tended to decrease igf1 gene expression (not statistically detectable), consistent with the slight suppression of basal igf1 gene expression by insulin seen in vitro. However, co-injection of $\mathrm{GH}$ and insulin increased igf1 gene expression versus $\mathrm{GH}$ alone, which differs from our in vitro results. This may have been an indirect effect of insulin. In brown trout, insulin injection increased plasma Igf1 3 h later (Banos et al. 1999), even though in coho salmon hepatocytes, insulin did not affect basal igf1 and suppressed GH-stimulated igf1 (Pierce et al. 2005), suggesting that indirect stimulatory effects of insulin on liver Igf1 production may exist in salmonids. In this study, GH-stimulated hepatic igf2 mRNA levels to a biologically significantly greater degree than igf1 mRNA levels in vitro and in vivo, consistent with recent results in $\mathrm{GH}$ transgenic tilapia (Eppler et al. 2010). This suggests that liverderived endocrine Igf2 may play a larger role than liverderived endocrine Igf1 in mediating the growth-stimulating effects of $\mathrm{GH}$ in tilapia.

Insulin plays a central role in the regulation of liver Igf1 production in mammals. Insulin secretion into the hepatic portal vessels results in exposure of the liver to high concentrations of insulin. Maintenance of insulin levels is necessary to maintain liver GH sensitivity, liver igf1 gene expression, blood Igf1 levels, and growth (Griffen et al. 1987, Rodgers et al. 1994, Thissen et al. 1994, Phillips et al. 1998, Butler et al. 2003). Insulin levels in the portal vessels are also elevated in fish (Plisetskaya \& Sullivan 1989). In mammalian and avian primary hepatocyte culture, insulin increases basal, and GH-dependent Igf1 mRNA level and protein secretion (Tollet et al. 1990, Boni-Schnetzler et al. 1991, Houston \& O’Neill 1991, Denver \& Nicoll 1994, Phillips et al. 1998). The results of the present and our previous studies suggest that the regulatory linkage between the pancreatic islets and the liver may also operate in fish, in the regulation of liver Igf2 production.

The differences found between mammals and fish in the regulation of liver igf $\mathrm{mRNA}$ levels by $\mathrm{GH}$ and insulin implies divergence of gene regulation. In mammals, current models suggest that GH stimulation of liver Igf1 transcription is mediated by binding of the transcription factor Stat5b to multiple enhancer sites dispersed across at least $135 \mathrm{~kb}$ throughout the Igf1 locus (Rosenfeld \& Hwa 2009, Chia et al. 2010). In fish, GH can stimulate liver igf1 transcription via Stat5 and the liver-specific transcription factor Hnf- $1 \alpha$ (Meton et al. 1999, Vong et al. 2003b), suggesting that this pathway may be conserved. In salmonids, GH stimulation of igf2 gene expression has been proposed to be mediated by transcription factors in the CCAAT/enhancer-binding protein (C/EBP) family (Shamblott et al. 1998, Palamarchuk et al. 2001). In rainbow trout, $\mathrm{GH}$ treatment increased liver igf2 gene expression but reduced liver $\mathrm{C} / \mathrm{EBP} \beta 2$ occupancy of binding sites dispersed over at least $5 \mathrm{~kb}$ in the igf 2 locus, suggesting that the role of C/EBP 2 may be negative (Lo et al. 2007, Lo \& Chen 2010). However, in carp, an igf2 promoter region sufficient for response to $\mathrm{GH}$ did not contain binding sites for $\mathrm{C} / \mathrm{EBP}$, Stat, or Hnf family transcription factors (Tse et al. 2008). The discrepancies between studies may be due to the operation of multiple long-range enhancers. Further studies are required to determine the transcription factors and gene regulatory elements that mediate $\mathrm{GH}$ stimulation of igf2 transcription in tilapia. 
In rats, an igf1 promoter positive response element that interacts with a novel insulin-response element-binding protein (IRE-BP1) downstream of PI3-kinase has been identified (Villafuerte et al. 2004). Insulin regulation of fish igf 2 promoters has not been investigated.

In the presence of $\mathrm{GH}$, cortisol reduced igf 1 and increased igf2 mRNA levels in tilapia hepatocytes. Modulation of $\mathrm{GH}$ response occurred at $10^{-8}-10^{-6} \mathrm{M}$ cortisol, coinciding with the physiological range from basal to stressed in tilapia (Balm et al. 1994, Breves et al. 2010). Cortisol injection reduced liver igf1 gene expression and circulating Igf1 in vivo in tilapia (Kajimura et al. 2003). In sea bream hepatocytes, cortisol reduced basal igf1 mRNA levels at physiological concentrations (Leung et al. 2008), and in coho salmon hepatocytes, the glucocorticoid receptor agonist dexamethasone strongly inhibited GH-stimulated igf1 mRNA levels (Pierce et al. 2005). Thus, glucocorticoid suppression of igf1 expression, either directly or via $\mathrm{GH}$ resistance, appears to be conserved in teleost fishes. Glucocorticoids reduce liver IGF1 production in mammals (Rodgers et al. 1994, Brameld et al. 1995, Beauloye et al. 1999). This study and our previous study in coho salmon hepatocytes show glucocorticoid stimulation of igf2 mRNA levels, either directly or via enhanced GH response (Pierce et al. 2010). Therefore, the most reasonable hypothesis at this point is that glucocorticoids inversely regulate liver production of Igf1 and Igf2 in fishes. This suggests that liver-derived endocrine Igf1 and Igf2 may have different functions in fishes. It is possible that the two Igfs differentially regulate organ and tissue growth. Cortisol increases in fishes during life history transitions in which tissue remodeling and differential growth occur, such as salinity adaptation, smoltification in salmonids, and reproductive maturation.

This and other studies provide evidence that liver-derived endocrine Igf2 may be a somatomedin in tilapia and other teleost fishes. Studies on the function of Igf2 in fish support this idea. In tilapia, administration of either recombinant native Igf1- or Igf2-stimulated growth (Chen et al. 2000). Circulating Igf 2 is regulated by metabolic status in salmonids (Wilkinson et al. 2006). Both Igfs stimulated mitogenic endpoints in zebrafish embryos (Pozios et al. 2001), and rainbow trout muscle cell culture (Codina et al. 2008). Both Igfs exert negative feedback on pituitary GH secretion (Fruchtman et al. 2000). If endocrine Igf2 is a somatomedin in fishes, then both Igfs should be taken into account in applications of growth endocrinology in fisheries management, conservation, and aquaculture. Plasma levels of both Igfs may be useful indicators of growth status in wild and captive fishes (Picha et al. 2008a). Plasma levels of both Igfs may provide information on energetic status to neuroendocrine systems that regulate major life history transitions, such as smolting and reproductive maturation (Dickhoff et al. 1997, Luckenbach et al. 2010). Clearly, conclusions regarding Igf2 physiology based on experiments in mammalian model systems cannot be extended to teleost fishes (White et al. 2009). Further study of the physiology of the two Igfs from a comparative perspective will clarify the functional evolution of the GH/Igf system (O'Neill et al. 2007), and may provide an answer to 'the Igf2 enigma' (Humbel 1990, Holly 1998).

\section{Declaration of interest}

The authors declare that there is no conflict of interest that could be perceived as prejudicing the impartiality of the research reported.

\section{Funding}

This project was supported by National Research Initiative Competitive Grants nos 2006-35206-16647 and 2008-35206-18785 from the USDA National Institute of Food and Agriculture and by National Science Foundation Grants nos IOB05-17769 and OISE08-52518.

\section{Acknowledgements}

We thank the members of the Grau lab for assistance: Dr Darren Lerner, Dr Kai Fox, Dr Lori Davis, Nancy Visitacion, Eli Witt, Anna Kosztowny, Masa Yoshioka, and Ryan Helms. We thank the anonymous referees and statistical reviewer whose comments improved this paper.

\section{References}

Ayson FG, de Jesus-Ayson EG \& Takemura A 2007 mRNA expression patterns for GH, PRL, SL, IGF-I and IGF-II during altered feeding status in rabbitfish, Siganus guttatus. General and Comparative Endocrinology $\mathbf{1 5 0}$ 196-204. (doi:10.1016/j.ygcen.2006.08.001)

Balm PH, Pepels P, Helfrich S, Hovens ML \& Bonga SE 1994 Adrenocorticotropic hormone in relation to interrenal function during stress in tilapia (Oreochromis mossambicus). General and Comparative Endocrinology 96 347-360. (doi:10.1006/gcen.1994.1190)

Banos N, Planas JV, Gutierrez J \& Navarro I 1999 Regulation of plasma insulin-like growth factor-I levels in brown trout (Salmo trutta). Comparative Biochemistry and Physiology 124C 33-40.

Beauloye V, Ketelslegers JM, Moreau B \& Thissen JP 1999 Dexamethasone inhibits both growth hormone $(\mathrm{GH})$-induction of insulin-like growth factor-I (IGF-I) mRNA and GH receptor (GHR) mRNA levels in rat primary cultured hepatocytes. Growth Hormone and IGF Research $9205-$ 211. (doi:10.1054/ghir.1999.0110)

Boni-Schnetzler M, Schmid C, Meier PJ \& Froesch ER 1991 Insulin regulates insulin-like growth factor I mRNA in rat hepatocytes. American Journal of Physiology 260 E846-E851.

Brameld JM, Weller PA, Saunders JC, Buttery PJ \& Gilmour RS 1995 Hormonal control of insulin-like growth factor-I and growth hormone receptor mRNA expression by porcine hepatocytes in culture. Journal of Endocrinology 146 239-245. (doi:10.1677/joe.0.1460239)

Breves JP, Hirano T \& Grau EG 2010 Ionoregulatory and endocrine responses to disturbed salt and water balance in Mozambique tilapia exposed to confinement and handling stress. Comparative Biochemistry and Physiology 155A 294-300. (doi:10.1016/j.cbpa.2009.10.033)

Butler ST, Marr AL, Pelton SH, Radcliff RP, Lucy MC \& Butler WR 2003 Insulin restores $\mathrm{GH}$ responsiveness during lactation-induced negative energy balance in dairy cattle: effects on expression of IGF-I and GH receptor 1A. Journal of Endocrinology 176 205-217. (doi:10.1677/joe.0.1760205)

Carnevali O, Cardinali M, Maradonna F, Parisi M, Olivotto I, PolzonettiMagni AM, Mosconi G \& Funkenstein B 2005 Hormonal regulation of hepatic IGF-I and IGF-II gene expression in the marine teleost Sparus aurata. Molecular Reproduction and Development 71 12-18. (doi:10.1002/mrd.20122) 
Chen J-Y, Chen J-C, Chang C-Y, Shen S-C, Chen M-S \& Wu J-L 2000 Expression of recombinant tilapia insulin-like growth factor-I and stimulation of juvenile tilapia growth by injection of recombinant IGFs polypeptides. Aquaculture 181 347-360. (doi:10.1016/S0044-8486(99)00239-2)

Chia DJ, Varco-Merth B \& Rotwein P 2010 Dispersed chromosomal Stat5bbinding elements mediate growth hormone-activated insulin-like growth factor-I gene transcription. Journal of Biological Chemistry 285 17636-17647. (doi:10.1074/jbc.M110.117697)

Codina M, Garcia de la serrana D, Sanchez-Gurmaches J, Montserrat N, Chistyakova O, Navarro I \& Gutierrez J 2008 Metabolic and mitogenic effects of IGF-II in rainbow trout (Oncorhynchus mykiss) myocytes in culture and the role of IGF-II in the PI3K/Akt and MAPK signalling pathways. General and Comparative Endocrinology 157 116-124. (doi:10.1016/j.ygcen. 2008.04.009)

Denver RJ \& Nicoll CS 1994 Pancreatic hormones differentially regulate insulin-like growth factor (IGF)-I and IGF-binding protein production by primary rat hepatocytes. Journal of Endocrinology 142 299-310. (doi:10. 1677/joe.0.1420299)

Devlin RH, Sakhrani D, Tymchuk WE, Rise ML \& Goh B 2009 Domestication and growth hormone transgenesis cause similar changes in gene expression in coho salmon (Oncorhynchus kisutch). PNAS 106 3047-3052. (doi:10.1073/pnas.0809798106)

Dickhoff WW, Beckman BR, Larsen DA, Duan C \& Moriyama S 1997 The role of growth in endocrine regulation of salmonid smoltification. Fish Physiology and Biochemistry 17 231-236. (doi:10.1023/A:1007710308765)

Eppler E, Berishvili G, Mazel P, Caelers A, Hwang G, Maclean N \& Reinecke M 2010 Distinct organ-specific up- and down-regulation of IGF-I and IGF-II mRNA in various organs of a GH-overexpressing transgenic Nile tilapia. Transgenic Research 19 231-240. (doi:10.1007/s11248-009-9314-8)

Fox BK, Breves JP, Hirano T \& Grau EG 2009 Effects of short- and long-term fasting on plasma and stomach ghrelin, and the growth hormone/insulinlike growth factor I axis in the tilapia, Oreochromis mossambicus. Domestic Animal Endocrinology 37 1-11. (doi:10.1016/j.domaniend.2009.01.001)

Fruchtman S, Jackson L \& Borski R 2000 Insulin-like growth factor I disparately regulates prolactin and growth hormone synthesis and secretion: studies using the teleost pituitary model. Endocrinology 141 2886-2894. (doi:10.1210/en.141.8.2886)

Gabillard JC, Kamangar BB \& Montserrat N 2006 Coordinated regulation of the GH/IGF system genes during refeeding in rainbow trout (Oncorhynchus mykiss). Journal of Endocrinology 191 15-24. (doi:10.1677/joe.1.06869)

Gahr SA, Vallejo RL, Weber GM, Shepherd BS, Silverstein JT \& Rexroad CE III 2008 Effects of short-term growth hormone treatment on liver and muscle transcriptomes in rainbow trout (Oncorhynchus mykiss). Physiological Genomics 32 380-392. (doi:10.1152/physiolgenomics.00142.2007)

Goya L, de la Puente A, Ramos S, Martin MA, Escriva F \& Pascual-Leone AM 1999 Regulation of insulin-like growth factor-I and -II by glucose in primary cultures of fetal rat hepatocytes. Journal of Biological Chemistry $\mathbf{2 7 4}$ 24633-24640. (doi:10.1074/jbc.274.35.24633)

Griffen SC, Russell SM, Katz LS \& Nicoll CS 1987 Insulin exerts metabolic and growth-promoting effects by a direct action on the liver in vivo: clarification of the functional significance of the portal vascular link between the beta cells of the pancreatic islets and the liver. PNAS $\mathbf{8 4}$ 7300-7304. (doi:10.1073/pnas.84.20.7300)

Haig D 1993 Genetic conflicts in human pregnancy. Quarterly Review of Biology 68 495-532. (doi:10.1086/418300)

Holly JMP 1998 Editorial: the IGF-II enigma. Growth Hormone and IGF Research 8 183-184. (doi:10.1016/S1096-6374(98)80109-3)

von Horn H, Ekstrom C, Ellis E, Olivecrona H, Einarsson C, Tally M \& Ekstrom TJ 2002 GH is a regulator of IGF2 promoter-specific transcription in human liver. Journal of Endocrinology 172 457-465. (doi:10.1677/joe.0.1720457)

Houston B \& O'Neill IE 1991 Insulin and growth hormone act synergistically to stimulate insulin-like growth factor-I production by cultured chicken hepatocytes. Journal of Endocrinology 128 389-393. (doi:10.1677/joe.0. 1280389)

Humbel RE 1990 Insulin-like growth factors I and II. European Journal of Biochemistry 190 445-462. (doi:10.1111/j.1432-1033.1990.tb15595.x)

Jones JI \& Clemmons DR 1995 Insulin-like growth factors and their binding proteins: biological actions. Endocrine Reviews 16 3-34. (doi:10.1210/er.16.1.3)
Kajimura S, Uchida K, Yada T, Riley LG, Byatt JC, Collier RJ, Aida K, Hirano T \& Grau EG 2001 Stimulation of insulin-like growth factor-I production by recombinant bovine growth hormone in Mozambique tilapia, Oreochromis mossambicus. Fish Physiology and Biochemistry 25 221-230. (doi:10.1023/A:1022268811599)

Kajimura S, Hirano T, Visitacion N, Moriyama S, Aida K \& Grau EG 2003 Dual mode of cortisol action on GH/IGF-I/IGF binding proteins in the tilapia, Oreochromis mossambicus. Journal of Endocrinology 178 91-99. (doi:10. 1677/joe.0.1780091)

Leung LY, Kwong AK, Man AK \& Woo NY 2008 Direct actions of cortisol, thyroxine and growth hormone on IGF-I mRNA expression in sea bream hepatocytes. Comparative Biochemistry and Physiology 151A 705-710. (doi:10.1016/j.cbpa.2008.08.023)

Lo JH \& Chen TT 2010 CCAAT/enhancer binding protein beta 2 is involved in growth hormone-regulated insulin-like growth factor-II gene expression in the liver of rainbow trout (Oncorhynchus mykiss). Endocrinology 151 2128-2139. (doi:10.1210/en.2009-0960)

Lo JH, Chiou PP, Lin CM \& Chen TT 2007 Molecular cloning and expression analysis of rainbow trout (Oncorhynchus mykiss) CCAAT/enhancer binding protein genes and their responses to induction by GH in vitro and in vivo. Journal of Endocrinology 194 393-406. (doi:10.1677/JOE-07-0085)

Luckenbach JA, Dickey JT \& Swanson P 2010 Regulation of pituitary GnRH receptor and gonadotropin subunits by IGF1 and GnRH in prepubertal male coho salmon. General and Comparative Endocrinology 167 387-396. (doi:10.1016/j.ygcen.2009.09.010)

Meton I, Boot EP, Sussenbach JS \& Steenbergh PH 1999 Growth hormone induces insulin-like growth factor-I gene transcription by a synergistic action of STAT5 and HNF-1 alpha. FEBS Letters 444 155-159. (doi:10. 1016/S0014-5793(99)00064-2)

Mommsen TP \& Plisetskaya EM 1991 Insulin in fishes and agnathans: history, structure, and metabolic regulation. Reviews in Aquatic Sciences 4 225-259.

Moriyama S, Oda M, Yamazaki T, Yamaguchi K, Amiya N, Takahashi A, Amano M, Goto T, Nozaki M, Meguro H et al. 2008a Gene structure and functional characterization of growth hormone in dogfish, Squalus acanthias. Zoological Science 25 604-613. (doi:10.2108/zsj.25.604)

Moriyama S, Yamaguchi K, Takasawa T, Chiba H \& Kawauchi H 2008 b Identification of two insulin-like growth factor IIs in the Japanese eel, Anguilla japonica: cloning, tissue distribution, and expression after growth hormone treatment and seawater acclimation. Comparative Biochemistry and Physiology 149B 47-57.

Olivecrona H, Hilding A, Ekstrom C, Barle H, Nyberg B, Moller C, Delhanty PJ, Baxter RC, Angelin B, Ekstrom TJ et al. 1999 Acute and short-term effects of growth hormone on insulin-like growth factors and their binding proteins: serum levels and hepatic messenger ribonucleic acid responses in humans. Journal of Clinical Endocrinology and Metabolism 84 553-560. (doi:10. $1210 /$ jc.84.2.553)

O'Neill MJ, Lawton BR, Mateos M, Carone DM, Ferreri GC, Hrbek T, Meredith RW, Reznick DN \& O'Neill RJ 2007 Ancient and continuing Darwinian selection on insulin-like growth factor II in placental fishes. PNAS 104 12404-12409. (doi:10.1073/pnas.0705048104)

Palamarchuk AY, Kavsan VM, Sussenbach JS \& Holthuizen PE 2001 The chum salmon insulin-like growth factor II promoter requires Sp1 for its activation by C/EBPbeta. Molecular and Cellular Endocrinology 172 57-67. (doi:10.1016/S0303-7207(00)00381-6)

Peterson BC \& Waldbieser GC 2009 Effects of fasting on IGF-I, IGF-II, and IGF-binding protein mRNA concentrations in channel catfish (Ictalurus punctatus). Domestic Animal Endocrinology 37 74-83. (doi:10.1016/j. domaniend.2009.03.004)

Peterson BC, Waldbieser GC \& Bilodeau L 2004 IGF-I and IGF-II mRNA expression in slow and fast growing families of USDA103 channel catfish (Ictalurus punctatus). Comparative Biochemistry and Physiology 139A 317-323. (doi:10.1016/j.cbpb.2004.09.015)

Peterson BC, Waldbieser GC \& Bilodeau L 2005 Effects of recombinant bovine somatotropin on growth and abundance of mRNA for IGF-I and IGF-II in channel catfish (Ictalurus punctatus). Journal of Animal Science $\mathbf{8 3}$ 816-824. 
Phillips LS, Pao CI \& Villafuerte BC 1998 Molecular regulation of insulin-like growth factor-I and its principal binding protein, IGFBP-3. Progress in Nucleic Acid Research and Molecular Biology 60 195-265. (doi:10.1016/ S0079-6603(08)60894-6)

Picha ME, Turano MJ, Beckman BR \& Borski RJ 2008a Endocrine biomarkers of growth and applications to aquaculture: a minireview of growth hormone, insulin-like growth factor (IGF)-I, and IGF-binding proteins as potential growth indicators in fish. North American Journal of Aquaculture 70 196-211. (doi:10.1577/A07-038.1)

Picha ME, Turano MJ, Tipsmark CK \& Borski RJ $2008 b$ Regulation of endocrine and paracrine sources of Igfs and GH receptor during compensatory growth in hybrid striped bass (Morone chrysops $\times$ Morone saxatilis). Journal of Endocrinology 199 81-94. (doi:10.1677/JOE-07-0649)

Pierce AL, Dickey JT, Larsen DA, Fukada H, Swanson P \& Dickhoff WW 2004 A quantitative real-time RT-PCR assay for salmon IGF-I mRNA, and its application in the study of GH regulation of IGF-I gene expression in primary culture of salmon hepatocytes. General and Comparative Endocrinology 135 401-411. (doi:10.1016/j.ygcen.2003.10.010)

Pierce AL, Fukada H \& Dickhoff WW 2005 Metabolic hormones modulate the effect of growth hormone (GH) on insulin-like growth factor-I (IGF-I) mRNA level in primary culture of salmon hepatocytes. Journal of Endocrinology 184 341-349. (doi:10.1677/joe.1.05892)

Pierce AL, Fox BK, Davis LK, Visitacion N, Kitahashi T, Hirano T \& Grau EG 2007 Prolactin receptor, growth hormone receptor, and putative somatolactin receptor in Mozambique tilapia: tissue specific expression and differential regulation by salinity and fasting. General and Comparative Endocrinology 154 31-40. (doi:10.1016/j.ygcen.2007.06.023)

Pierce AL, Dickey JT, Felli L, Swanson P \& Dickhoff WW 2010 Metabolic hormones regulate basal and growth hormone-dependent igf2 mRNA level in primary cultured coho salmon hepatocytes: effects of insulin, glucagon, dexamethasone, and triiodothyronine. Journal of Endocrinology 204 331-339. (doi:10.1677/JOE-09-0338)

Plisetskaya EM \& Sullivan CV 1989 Pancreatic and thyroid hormones in rainbow trout (Salmo gairdneri): what concentration does the liver see? General and Comparative Endocrinology 75 310-315. (doi:10.1016/0016-6480(89)90084-1)

Ponce M, Infante C, Funes V \& Manchado M 2008 Molecular characterization and gene expression analysis of insulin-like growth factors I and II in the redbanded seabream, Pagrus auriga: transcriptional regulation by growth hormone. Comparative Biochemistry and Physiology 150B 418-426. (doi:10. 1016/j.cbpb.2008.04.013)

Pozios KC, Ding J, Degger B, Upton Z \& Duan C 2001 IGFs stimulate zebrafish cell proliferation by activating MAP kinase and PI3-kinasesignaling pathways. American Journal of Physiology 280 R1230-R1239.

Reinecke M \& Collet C 1998 The phylogeny of the insulin-like growth factors. International Review of Cytology 183 1-94. (doi:10.1016/S00747696(08)60142-4)

Rodgers BD, Lau AO \& Nicoll CS 1994 Hypophysectomy or adrenalectomy of rats with insulin-dependent diabetes mellitus partially restores their responsiveness to growth hormone. Proceedings of the Society for Experimental Biology and Medicine 207 220-226.

Rosenfeld RG \& Hwa V 2009 The growth hormone cascade and its role in mammalian growth. Hormone Research 71 36-40. (doi:10.1159/000192434)

Schmid AC, Reinecke M \& Kloas W 2000 Primary cultured hepatocytes of the bony fish, Oreochromis mossambicus, the tilapia: a valid tool for physiological studies on IGF-I expression in liver. Journal of Endocrinology 166 265-273. (doi:10.1677/joe.0.1660265)

Shamblott MJ, Cheng CM, Bolt D \& Chen TT 1995 Appearance of insulinlike growth factor mRNA in the liver and pyloric ceca of a teleost in response to exogenous growth hormone. PNAS 92 6943-6946. (doi:10. 1073/pnas.92.15.6943)

Shamblott MJ, Leung S, Greene MW \& Chen TT 1998 Characterization of a teleost insulin-like growth factor II (IGF-II) gene: evidence for promoter CCAAT/enhancer-binding protein $(\mathrm{C} / \mathrm{EBP})$ sites, and the presence of hepatic C/EBP. Molecular Marine Biology and Biotechnology 7 181-190.

Specker JL, King DS, Nishioka RS, Shirahata K, Yamaguchi K \& Bern HA 1985 Isolation and partial characterization of a pair of prolactins released in vitro by the pituitary of a cichlid fish, Oreochromis mossambicus. PNAS $\mathbf{8 2}$ 7490-7494. (doi:10.1073/pnas.82.22.7490)
Stratikopoulos E, Szabolcs M, Dragatsis I, Klinakis A \& Efstratiadis A 2008 The hormonal action of IGF1 in postnatal mouse growth. PNAS 105 19378-19383. (doi:10.1073/pnas.0809223105)

Tatar M, Bartke A \& Antebi A 2003 The endocrine regulation of aging by insulin-like signals. Science 299 1346-1351. (doi:10.1126/science.1081447)

Terova G, Rimoldi S, Chini V, Gornati R, Bernardini G \& Saroglia M 2007 Cloning and expression analysis of insulin-like growth factor I and II in liver and muscle of sea bass (Dicentrarchus labrax, L.) during long-term fasting and refeeding. Journal of Fish Biology 70 219-233. (doi:10.1111/j.1095-8649.2007.01402.x)

Thissen JP, Ketelslegers JM \& Underwood LE 1994 Nutritional regulation of the insulin-like growth factors. Endocrine Reviews 15 80-101. (doi:10. 1210/er.15.1.80)

Thissen JP, Underwood LE \& Ketelslegers JM 1999 Regulation of insulin-like growth factor-I in starvation and injury. Nutrition Reviews 57 167-176. (doi:10.1111/j.1753-4887.1999.tb06939.x)

Tollet P, Enberg B \& Mode A 1990 Growth hormone (GH) regulation of cytochrome P-450IIC12, insulin-like growth factor-I (IGF-I), and GH receptor messenger RNA expression in primary rat hepatocytes: a hormonal interplay with insulin, IGF-I, and thyroid hormone. Molecular Endocrinology 4 1934-1942. (doi:10.1210/mend-4-12-1934)

Tse MC, Vong QP, Cheng CH \& Chan KM 2002 PCR-cloning and gene expression studies in common carp (Cyprinus carpio) insulin-like growth factor-II. Biochimica et Biophysica Acta 1575 63-74. (doi:10.1016/S01674781(02)00244-0)

Tse MC, Chan KM \& Cheng CH 2008 Cloning, characterization and promoter analysis of the common carp IGF-II gene. Gene 412 26-38. (doi:10.1016/j.gene.2007.12.023)

Uchida K, Kajimura S, Riley LG, Hirano T, Aida K \& Grau EG 2003 Effects of fasting on growth hormone/insulin-like growth factor I axis in the tilapia, Oreochromis mossambicus. Comparative Biochemistry and Physiology 134A 429-439. (doi:10.1016/S1095-6433(02)00318-5)

Villafuerte BC, Phillips LS, Rane MJ \& Zhao W 2004 Insulin-response element-binding protein 1: a novel Akt substrate involved in transcriptional action of insulin. Journal of Biological Chemistry 279 36650-36659. (doi:10. 1074/jbc.M404349200)

Vong QP, Chan KM \& Cheng CH 2003a Quantification of common carp (Cyprinus carpio) IGF-I and IGF-II mRNA by real-time PCR: differential regulation of expression by GH. Journal of Endocrinology 178 513-521. (doi:10.1677/joe.0.1780513)

Vong QP, Chan KM, Leung K \& Cheng CH 2003 b Common carp insulinlike growth factor-I gene: complete nucleotide sequence and functional characterization of the $5^{\prime}$-flanking region. Gene 322 145-156. (doi:10. 1016/j.gene.2003.08.019)

Weber GM \& Grau EG 1999 Changes in serum concentrations and pituitary content of the two prolactins and growth hormone during the reproductive cycle in female tilapia, Oreochromis mossambicus, compared with changes during fasting. Comparative Biochemistry and Physiology 124 323-335. (doi:10.1016/S0742-8413(99)00081-X)

White YA, Kyle JT \& Wood AW 2009 Targeted gene knockdown in zebrafish reveals distinct intraembryonic functions for insulin-like growth factor II signaling. Endocrinology 150 4366-4375. (doi:10.1210/en.2009-0356)

Wilkinson RJ, Porter M, Woolcott H, Longland R \& Carragher JF 2006 Effects of aquaculture related stressors and nutritional restriction on circulating growth factors (GH, IGF-I and IGF-II) in Atlantic salmon and rainbow trout. Comparative Biochemistry and Physiology 145 214-224. (doi:10.1016/j.cbpa.2006.06.010)

Wood AW, Duan C \& Bern HA 2005 Insulin-like growth factor signaling in fish. International Review of Cytology 243 215-285. (doi:10.1016/S00747696(05)43004-1)

Received in final form 13 July 2011

Accepted 29 July 2011

Made available online as an Accepted Preprint 29 July 2011 